\title{
Internal Control Systems in Nepal: A Case of Nepal Telecom
}

Ballav Niroula ${ }^{1}$

${ }^{1}$ Faculty of Management Patandhoka-Patan Multiple Campus-Lalitpur-Nepal

Achut Gyawali ${ }^{2}$

${ }^{2}$ Department of Management-Tribhuvan University-Kathmandu-Nepal

Correspondence : ballavsir@gmail.com
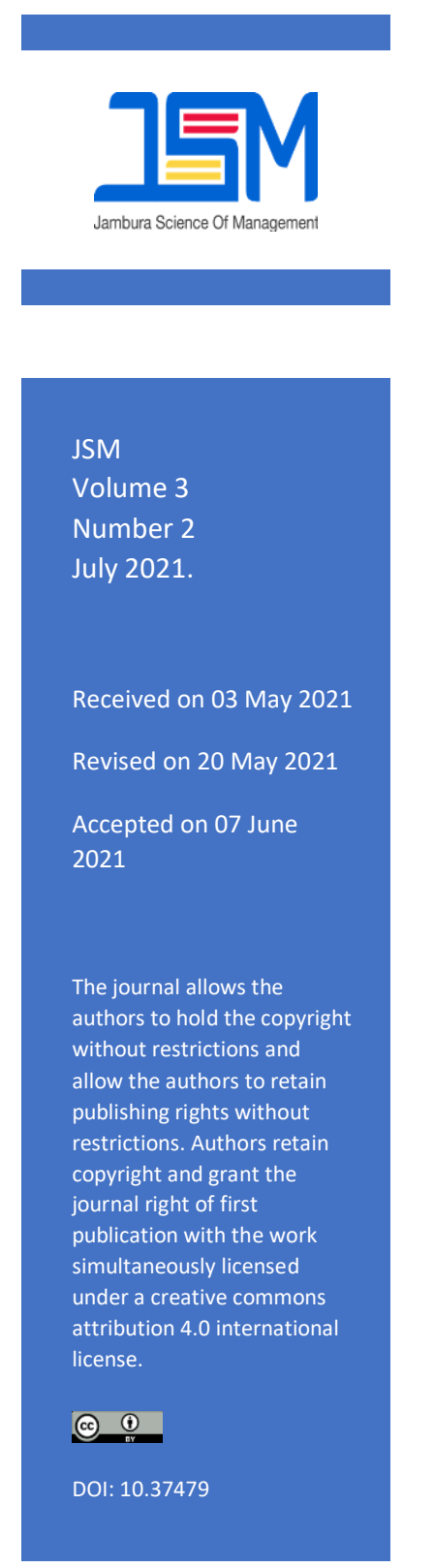

\section{ABSTRACT}

Purpose: The purpose of this study is to discover the efficacy of internal control system of Nepal Telecom.

Design/Methodology/Approarch: This study followed a case study research design, because it offers a deeper perspective and clearer understanding of the internal control system and its practices. The sample size of this study consisted of all the employees working at different level in Nepal Telecom. The convenience sampling method has been applied for selection of respondents. The researchers distributed 280 questionnaires out of them only 240 respondents returned usable questionnaires. This study was totally based on primary data. In order to make proper analysis descriptive and inferential statistics were used using SPSS software version 23.

Findings: The finding of this study showed that the control environment, risk assessment, control activities, communication and monitoring affects perceived performance of organization. Effective internal control system helped to increase working efficiency also. The recommendations were made that the company should emphasize the required internal organizational management structure to be implemented. This is because of the internal organizational management structure positively affects the execution of strategies and policies, thereby achieving a sustainable competitive advantage and increment of profit.

Keywords: Communication; Internal Control System; Monitoring; Risk Assessment.

\section{INTRODUCTION}

The mechanism that developed and able to carry out duties for governance, management and staffs consider as Internal Control. It provides equal opportunity to achieve their goals of an agency's achievements with regard to the performance of financial reports, the productivity and reliability of operations, and compliance with relevant laws and regulations (Mwindi, 2005). In order to assess reasonableness, effectiveness decision and able to find out abnormality and unknowing condition help to make decision on risk 
management activities by internal control (Armour, 2000). The main role of internal control is to create suitable and collaborative environment under control environment (Burtev, 2000). Dinapoli (2003) found that an internal management structure will accomplish its goals and purpose by incorporating the actions, strategies, behaviors and determination of the works who work in the organization.

COSO (1992) described internal control as a concept carried out by the Board of Directors, the management of the company or other staff to provide fair assurance that the following targets and results of operations will be achieved, to drive results, to ensure the country (International standards laws professional practice of internal auditing ,2012). According to the COSO, the system of internal control consists of five interrelated components: (1) Control environment; (2) Risk assessment; (3) Actions for the implementation of the control; (4) Information and communication; (5) Monitoring.

Arena, Arnaboldi and Azzone (2006) found that effectiveness is consider to obtain the result that are stable with target objectives. Internal control can be defined as effective in that condition when the efficiency of financial reporting consistent with effectiveness of operating and compliance accordance to law and regulations. There is effective internal control when the organization's assets can be safeguarded and accurate financial statements can be generated. Adejola (2009) explained the following fundamental variables are considered present, control is said to be efficient and reliable. They include the factor of Heaven, the factor of time management, the factor of information, ICT variables, and the factor of competence and honesty.

Internal control system is a regulation that can ensure the organization operating activities in proper with rule and regulation of organization and it will minimize the avoid waste of work, theft and inappropriate used of organization resources (Nidifon \& Patrick, 2014). Marah (2007) mentioned that Internal monitoring as well as scheduled steps to ensure the accomplishment of targets are instituted by an organization. Management has agreed guidelines and regulations to further strengthen the working climate, which in turn allows the company to accomplish its goals. Gyamfi (2007) highlights the reasons why businesses need internal controls that avoid items such as assets, documents and records from missing but benefiting, people inside or outside an organization, makes sense of how the company does, avoids.

According to COSO Internal control framework "The good internal control system provide assurance regarding organization objectives. To maintain good internal control system all the three category of objectives each of the five need to contain as an objectives." To making ensure whether internal control is effective to senior, management and board of directors need to determine at what extent 
need to follow the regulation.

In Nepal, Telecom Company also has grown as fast as compare to other developing country telecommunication company and Nepal Door Sanchar Company (NTC) Ltd. popularly known as Nepal telecom and it is state owned telecommunication service provider in Nepal. NTC have grown so fast due to their varieties of internet services like data package, $\mathrm{Wi}-\mathrm{Fi} 4 \mathrm{G}$ internet services and so on. There are also other private operator companies establish in Nepal like UTL and Ncell though NTC become most popular among Nepalese costumers. It became interesting to find how NTC effectively handling internal control system. Thus, this study aims to assess the effectiveness of internal control system of Nepal telecom which is public enterprises. Furthermore, it also aims to identify present status of internal control system of Nepal telecom.

Internal control system become an interesting avenue for current research in the organization sector. Since Nepal Telecom entity as a trustworthy organization. It seems that internal control system of NTC is quite good and this study explore that there any relationship between internal control system and perceived performance and access the association between international control system and performance of NTC. This study exploration will help to researcher to examine another organization internal control system and perceived performance.

Nepal Telecom is the country's oldest and largest telecommunications provider. The company, which is 51 percent owned by the Nepalese government and has an NPR 485 billion equity and over 5400 employees, has been in operation. The organization has contributed more than $80 \%$ in the field of telecommunications through 262 telephone exchanges across the world. (2016/17 Annual Report) In a broad and multi-staffed company, it is difficult to implement an efficient internal control system; however, Nepal Telecom has made significant efforts to do so. According to auditing standards (SAS 300), internal control defined to achieve their objective that is adopted by organizations while following their policies and procedure. Moreover, internal control consistent practicable, efficient conduct and adherence to internal policies, prevention of fraud as well accuracy of accounting records and reliable financial information.

Arena, Arnaboldi and Azzone (2006) mentioned that to achieve the targets need effectiveness and it is potential to produce outcome. Internal control can be deemed to be efficient if it meets its core goals of financial reporting reliability, organizational quality and effectiveness, and compliance with legislation and regulations. There is effective internal control when the organizations' assets can be safeguarded and accurate financial statements can be generated.

Intosai, (2001) found that the in the entity author they designed the regulation that it can all of resourced need utilize at optimum level 
and service with less cost. The next significant step after the authority sets out the goals of the business is to recognize threats that might arise in order to achieve the goals. Authority is a single process and reasonably controlled processes are structured to clarify available resource are utilized at maximum that products or services of high quality are produced and that costs are reduced. In the organization after the authority lays out the company target, the most challenging part is to achieve the goals (Beasley, 2007).

Ayagre (2014) found in their study using COSOs principles and attributes of assessing the effectiveness of internal control system in Ghanain Banks. Kingdom et al. ( 2019) investigated about dishonest of employee on work through internal control. The study found the division of duties and the existence of control operations increase the cost of fraud. Therefore, internal control system become a vital issue for an entity and it needed specially for state owned firm that have unlimited distributed power in organization and NTC also is one of state own organization and this study can fill the gap of internal control system in Nepalese state owned organization.

Boakye (2016) found that the role of internal control in public sector a case study of Edweso government hospital and it has been effective ay hospital. Similarly, Hailemarin (2014) studied on determinates of internal audit effectiveness in the public sector: case study in selected Ethiopian public sector offices, also found effective internal control system in Ethiopian public sector. On the other hand, Sarens, Visscher and Vangils, (2010) Risk management and internal control in public sector. An in depth analysis of Belgium social security public institutions, found risk management and internal control are not highly developed which have different findings. And Aduam, J. (2015) Assessing the effectiveness of internal controls mechanism of the Techiman Municipal Assembly have also different finding which find out that internal control procedures are not strictly followed by TMA.

Shabri, saad and Bakar (2017) Analzed the impact of the internal control mechanism on the viability of the cooperative: case of koperasi ABC Berhad. The study used the qualitative method of research, the discussion of the focus group, key interviews with knowledge and documentary analysis. In organization the goal determined by their work and it impact to internal control system. They found that it could be considered that the internal control system implemented in koperasi ABC Berhad is efficient and satisfactory. It was based on the implementation, as defined by the COSO framework within the cooperative, of all components of the internal control systems. Ademola, Adedoyin and Alade (2015) mention about Nigeria's national petroleum corporation internal control system and used in the study distributed questionnaires data and chi-square statistical methods. In addition, they mentioned that Internal control play an important role to prevention fraud and irregularities.

P-ISSN: 2655-3651 E-ISSN: 2656-0435 P a g e | 102 
Musika and Upping (2014) found that RMUIT Sakon Nakhon campus who receiving government income is transparent and accordingly regulations through internal control. Moreover, the staff their acted responsibly that the government allocate the expenditure accordingly. Barisic and Tusek (2016) analyzed about the important about internal audit effectiveness in Croatian companies.

Ahmed \& Muhammed, (2018) the aim of this study was to determine the effects of internal controls on Asia cell's financial performance as a telecommunications company in Iraq's Kurdistan Region. This was accomplished by examining the impact of the control environment, risk management, information and communication, control operations, and reporting on the asset return. We used both primary and secondary data. The dependent variable was financial output, and the independent variables were internal control components. The study's results revealed a substantial association between internal controls and financial performance after analyzing the primary data. The study's dependent and independent variables revealed a connection to the control environment and risk assessment. The activities of information, communication, and control showed a positive relationship with financial performance, while monitoring showed a negative relationship with financial performance. The research also discovered that Asia cell had invested in powerful internal control systems, as a result of which it had a better financial record than similar companies with a poor internal control system. The study also suggests that the governing body, with the help of the audit committee, ensure that the internal control system is periodically monitored and evaluated by the respective managers.

\section{METHODS}

This study emphasis Internal Control system play vital role to run more effectively enterprises. As well organizations acquired the knowledge and attention of professional accounting organizations seeking to improve the principle of internal control in an ongoing manner. Internal control is characterized as the organizational strategy, coordination processes, initiatives and approaches adopted by top management to protect business assets, audit and review accounting information, ensure its integrity and accuracy, improve productivity skills, and encourage employees to comply with the administrative policy set (Salamah, 2010).

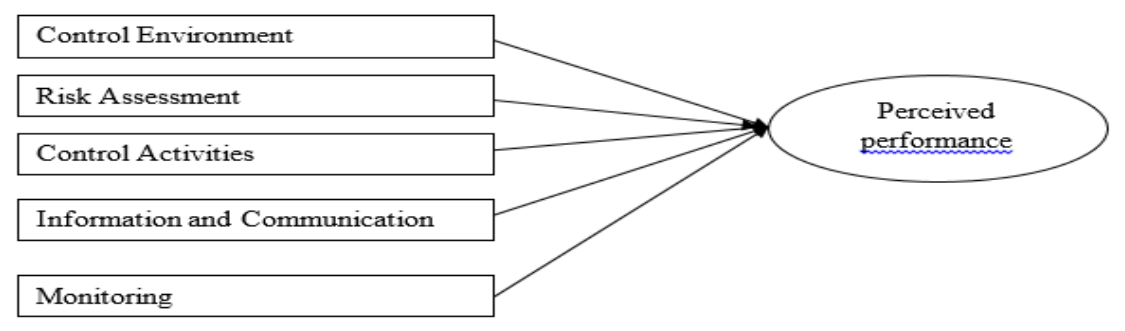

Figure 1. Conceptual Framework 


\section{Control Environment}

Superior management attitudes and oversight of control by a board of directors that is independent of management. It also develops structures, authorities and responsibilities that achieve management goals in addition to managing staff's responsibility for their responsibilities and attaching, improving and retaining the competent individuals (COSO 2011).

\section{Risk Assessment}

It is a management practice in which the risks related to the preparation of financial statements are calculated and assessed according to accounting steps. The management then determines the method of reaction to such risks in a manner that minimizes their effect on the financial statements and then reports the results. (International Audit Measure, 2007).

\section{Control Activities}

In addition to the control setting, the strategies and practices followed by management in order to achieve the company's objectives. Procedures consist of documentation, record consistency checking, and monitoring of computer information system systems and environments. (COSO, 2011).

\section{Information and Communication}

All relevant information both down and up to the company must be collected and shared by the internal control system and external parties must communicate information (Zwyalif, 2015).

\section{Monitoring}

Internal control systems for their adequacy need to be regularly monitored. It is important to report serious deficiencies to top management or the board of directors (Zwyalif, 2015).

\section{Dependent Variable}

It is perceived performance. The performance assessment requires financial criteria that represent the real picture and management of the business at all levels. A holistic vision for balancing the distribution of financial and financial measures is also needed. (Dorrah \& Sabbage, 2008). The following Hypothesis are bases on assumption to examine the relationship between control system and perceived performance.

$\mathrm{H}_{1}$ : There has been significant relationship between control environment and perceived performance.

$\mathrm{H}_{2}$ : There has been significant relationship between risks assessment and perceived performance.

$\mathrm{H}_{3}$ : There has been significant relationship between control activities 
and perceived performance.

$\mathrm{H}_{4}$ : There has been significant relationship between information and communication and perceived performance.

$\mathrm{H}_{5}$ : There has been significant relationship between monitoring and perceived performance.

This study based on the descriptive study, case study and casual research design. This study focus about the effectiveness of internal control system in Nepal Telecom. Within this major concern head office located in Bhadrakali plaza and office located in Sundhara of Nepal telecom taken as sample. In this study used 416 number of observation as population of study. The data used in this study is primary data. The data nature is regarding with views and opinions of the experienced employees working in various levels. The information required to achieve this purpose were collected through questionnaire survey.

From this population, the employees working in any level and to whom the researcher can meet first and former during field visit were selected as respondents. The employees only who felt comfortable to fill up questionnaire under the request of researcher were selected as sample respondents. In this way, by following the convenience sampling approach, all together 240 respondents, from Nepal telecom were selected as sample respondents to collect primary data especially the views on internal control system's present status, effectiveness of Nepal telecom. Employees were selected as on the convenience sample method.

The data collected through questionnaire from each respondent to get reliable and valid information.

The data also used secondary data and the data were collected from articles, books, published reports, Annual reports, Economic survey, related booklets. For gathering the required information, the research also visited the related websites.

For the responses gathered under rating question, score values were assigned with the principle of highest value factor ranked as most important factor. Similarly, for the responses of rating question, quantitative values were assigned to each factor on the basis of frequency percentage. In the study Likert scale questionnaire is used, were ( 1 refers to strongly disagree, 2 refers to disagree, 3 refers to Neutral, 4 refers to agree, 5 refers to strongly agree).

Secondary data were collected from annual reports of sample organizations, published books and articles etc. The collected data were processed into table depending upon the nature of data. Descriptive and inferential statistics were used to make proper analysis. Average Cronbach's alpha of dependent and independent variables is 0.782 which is greater than 0.65 means the instruments used in this research are considered to reliable. 


\section{RESULTS}

\section{Correlations}

Correlation between perceived performance and control environment, risks assessment, information and communication, control activities and monitoring. Correlations of these variables is shown below.

Table 1. Correlations Coefficient

\begin{tabular}{|c|c|c|c|}
\hline Variable & Instrument & RPP & Relationship \\
\hline \multirow[t]{3}{*}{$\mathrm{RCE}$} & Pearson correlation & $0.213^{*}$ & \multirow[t]{3}{*}{ Positive } \\
\hline & Sig(2tailed) & 0.019 & \\
\hline & $\mathrm{N}$ & 172 & \\
\hline \multirow[t]{3}{*}{ RRA } & Pearson correlation & $0.253 *$ & \multirow[t]{3}{*}{ Positive } \\
\hline & $\operatorname{Sig}(2$ tailed $)$ & 0.019 & \\
\hline & $\mathrm{N}$ & 172 & \\
\hline \multirow[t]{3}{*}{ RCA } & Pearson correlation & 0.179 & \multirow[t]{3}{*}{ Positive } \\
\hline & $\operatorname{Sig}(2$ tailed $)$ & 0.019 & \\
\hline & $\mathrm{N}$ & 172 & \\
\hline \multirow[t]{3}{*}{ RIC } & Pearson correlation & $0.260 *$ & \multirow[t]{3}{*}{ Positive } \\
\hline & Sig $(2$ tailed $)$ & 0.016 & \\
\hline & $\mathrm{N}$ & 172 & \\
\hline \multirow[t]{3}{*}{ RTM } & Pearson correlation & $0.311 * *$ & \multirow[t]{3}{*}{ Positive } \\
\hline & $\operatorname{Sig}(2$ tailed $)$ & 0.004 & \\
\hline & $\mathrm{N}$ & 172 & \\
\hline \multirow[t]{3}{*}{ RPP } & Pearson correlation & 1 & \multirow[t]{3}{*}{ Positive } \\
\hline & $\operatorname{Sig}(2$ tailed $)$ & & \\
\hline & $\mathrm{N}$ & 172 & \\
\hline
\end{tabular}

Source: Research Survey (2020) (*Correlation is significant at the

0.05 level, ** Correlation is significant at the 0.01 level)

From table the 1 Pearson correlation coefficient of control environments, risk assessment, control activities, monitoring and communication with perceived performance are moderately positive correlated. It also indicated that if internal control systems are increased perceived performance have also been increased.

\section{Regression Analysis}

The general purpose of multiple regression is to learn more about the relationship between several independent or predictor variables and dependent or criterion variable. In this study, the dependent variable is perceiving performance it includes working efficiency, cost control, performance and independent variable are control activities, risks assessment, information and communication, control activities and monitoring.

The line of regression is $Y=A+B X$

Multiple regression model

$Y_{1}=\alpha+\beta_{1} X_{1}+\beta_{2} X_{2}+\beta_{3} X_{3}+\beta_{4} X_{4}+\beta_{5} X_{5}+\mathrm{e}_{i}$

Where, 
$Y_{1}=$ Dependent variable (perceived performance)

Independent variable $\quad X_{1}=$ Control Environment, $X_{2}=$ Risks assessment, $X_{3}=$ Control activities, $X_{4}$ =Information and communication, $X_{5}=$ Monitoring, $\alpha=$ Constant,

$\beta_{1}=$ Coefficient of slope of regression model, $\mathrm{e}_{i}=$ Error term

Table 2. Regression - Model Summary

\begin{tabular}{|c|c|c|c|c|}
\hline Model & R & R Square & $\begin{array}{c}\text { Adjusted R } \\
\text { Square }\end{array}$ & $\begin{array}{c}\text { Std. Error of } \\
\text { the Estimate }\end{array}$ \\
\hline 1 & $0.699^{\mathrm{a}}$ & 0.489 & 0.48 & 1.85 \\
\hline
\end{tabular}

Model summary indicates the R-square also known as coefficient of determination which can help in explaining variance. The value of $\mathrm{R}$ square value as evident from Table 2 is 0.48 which means $48.3 \%$ variation perceived performance is explained by all independent variables. However, the remaining $51.7 \%(100 \%-48.3 \%)$ is still unexplained in this research.

Table 3. Multiple Regression

\begin{tabular}{|c|c|c|c|c|c|}
\hline Model & $\begin{array}{c}\text { Unstandardized } \\
\mathbf{B}\end{array}$ & $\begin{array}{c}\text { Coefficients } \\
\text { Std. Error }\end{array}$ & $\begin{array}{c}\text { Standard } \\
\text { Coefficients } \\
\text { Beta }\end{array}$ & T & Sig. \\
\hline Constant & .821 & 1.176 & & .698 & .487 \\
\hline CE & -.071 & .140 & -0.68 & -.505 & .614 \\
\hline RA & .081 & .115 & .074 & .709 & .480 \\
\hline CA & .378 & .100 & .406 & 3.768 & .001 \\
\hline IC & .036 & .076 & .306 & .477 & .635 \\
\hline M & .543 & .117 & .465 & 4.663 & .001 \\
\hline
\end{tabular}

Dependent variable: (Perceived performance)

Table 3 Control Environment, Risk assessment, Information and communication have insignificant which is more than 5\%. Control Activities and Monitoring is a significant which is less than $5 \%$. Monitoring have highly effect on perceived performance. Control activities have negative effect on perceived performance.

\section{Hypothesis Results}

Table 4. Hypothesis Results

\begin{tabular}{|c|l|c|c|}
\hline Hypothesis & \multicolumn{1}{|c|}{ Statement } & $\begin{array}{l}\text { P } \\
\text { value }\end{array}$ & $\begin{array}{l}\text { Accepted } \\
\text { Rejected }\end{array}$ \\
\hline H1 & $\begin{array}{l}\text { There is a significant relationship between } \\
\text { control environment and perceived } \\
\text { performance. }\end{array}$ & 0.614 & Rejected \\
\hline H2 & $\begin{array}{l}\text { There is a significant relationship between } \\
\text { risks assessment and perceived } \\
\text { performance. }\end{array}$ & 0.480 & Rejected \\
\hline H3 & $\begin{array}{l}\text { There is a significant relationship between } \\
\text { control activities and perceived } \\
\text { performance }\end{array}$ & 0.001 & Accepted \\
\hline
\end{tabular}

P-ISSN: 2655-3651 E-ISSN: 2656-0435 


\begin{tabular}{|c|l|c|c|}
\hline H4 & $\begin{array}{l}\text { There is a significant relationship between } \\
\text { information and communication and } \\
\text { perceived performance. }\end{array}$ & 0.635 & Rejected \\
\hline H5 & $\begin{array}{l}\text { There is a significant relationship between } \\
\text { monitoring and perceived performance }\end{array}$ & 0.001 & Accepted \\
\hline
\end{tabular}

\section{DISCUSSION}

The employees working in Nepal telecom have agreed that internal control system is effective (mean=3.89). Employees are becoming concerned about the internal control system which includes control environment, risks assessment. Information and communication, control activities and monitoring. Similarly, perceived performance which includes cost reduction, working efficiency, job satisfaction and transparency as mention in this research. For the internal control system needs to be considered all this aspects of internal control. The average mean of risks assessment is 3.67 , which means risks identification, risk factor considering minimizing risk factor, managing risks is appropriate. The average mean of information and communication is 4.01 , which indicates information providing and communication process is appropriate. In comparison information and communicating process is effective.

Though the study doesn't show the higher degree of relationship of all the independent variables such as perceived performance. The results of the study have shown a positive relationship between internal control system and perceived performance. According to multiple regression analysis, Control activities and Monitoring is significant which is less than 5\%. Most of the respondents pointed out the problems related to internal control system in the Nepal telecom are proper standard setting for achieving goal, difficult to measure the actual performance in some areas of activities, problem in assigning job, lack of implementation of works.

\section{CONCLUSION}

The study concludes that internal control system variables and perceived performance have positive relation. Which helps to increase profitability also. It is very essential on part of the organizations to continuously improve the organizational performance which is possible by effective internal control system. Control environment sets the tone of the company, thus influencing the control consciousness. It is the foundation of all other components of internal control. Internal control system helps to identify and manage risks of the organization. Monitoring is a process that assesses the quality of the system's performance over time. Effective monitoring helps to achieve organization goals. Organization have some problem which related with internal control system which are lacks of proper and accurate evaluation, problem related to job rotation, reward and punishment, proper personnel management, division of work, objective of compliance activities are unclear and organization suffer 
from management related problem.

The reason for investigation effectiveness of internal control system of Nepal telecom through variables internal control system and perceived performance is finding problems related to internal control system, is one works which help to increase good internal control system and work efficiency of the organization and leads to increase performance. It also helps to achieve organizational goals. Internal control system helps to increase organizational effectiveness and increase performance. The conclusion that we can make towards the explanation below is effective internal control system will give benefits for employees such as better position and better performance of organization.

\section{RECOMMENDATION}

As mentioned in the scope of this study, not adequate research on the effectiveness of internal control system in Nepal telecom. This study limited itself to Nepal telecom sample size, recommendations are therefore made for sample size in order to broaden research in this sector. And study only depend on data which collected through questionnaire method, further studies may use other process of data collection method like interview, discussion etc. Further study may focus on internal control systems variables individually.

In order to improve or establish an effective internal control system in organization, it is advisable to carry out detailed internal control system survey to identify the effectiveness of organization. In future, other manufacturing companies, Hospital, banking sector may be used in sample.

\section{REFERENCES}

Adagye, I. D., (2015). "Effective internal control system in the Nasarawa state Terticiry educational Institutions for efficiency: A case of Nasarawa state polytechnic, Lafia", International Journal Educational and pedagogical Sciences, 9(11) 39023907.

Ademola, I.S., Adedoyin, A. O. and Alade, O. R., (2015). "Effect of internal control system in Nigeria public sectors: A case study of Nigeria national petroleum corporation", International journal of economics commerce and management, 3(6),10931102 .

Ahmad, H.N. Othman, R., and use off, k., (2009). "The Effectiveness of Internal Audit in Malaysian Public sector". Journal of Mordern Accounting and Auditing,7(17),25

Ahmed, A. M., \& Muhammed, A. A. (2018). Internal control systems \& its relationships with the financial performance in telecommunication companies - a case study of Asiacelll. International Journal of Scientific and Technology Research, 
7(11), 82-88. https:// doi. org/10.29358/sceco.v0i28.416

Alzwayalif, I. M, (2015). "The role of internal control in enhancing corporate governance: Evidence from Jordan”. International Journal of Business and Management,10(7),57

Arena, M., Arnaboldi, M. and Azzone, G., (2006). "The Role of Internal Auditor in Italian Organisation: A Multiple Case Study”, Managerial Accounting Journal, 21 (3), 275-292

Armour, M. (2000). "Internal control: Governancae Framework and Business Risk Assessment at Reed Elsevier, Auditing", A Journal of Practice and theory,19 (10),19.

Ayagre, P. (2014). "The effectiveness of internal control systems of banks the case of Ghanain banks", International Journal of Accounting and Financial Reporting, 4(2), 377-389.

Barisic, I. and Tusek, B., (2016). The important of the supportive control environment for internal audit effectiveness: The Case of Croatian companies, Jimmy University.

Barlaw, P., Heberg, S., Large, N., and Le Roux. K., (2000). The business approach to intergrated Auditing, USA: New York Press

Beasley, M.S. (2007). "Development Effective Internal Controls Using the COSO Model Today's Objectives", London: Green Publication

Boakye, E. O., (2016). The role of internal control in the public sector A case study of EDWESO Government Hospital, University of Ghana.

Cascarino, R and Van Esch, S., (2007). Internal auditing: An integrated approach, Jersey City: Blue

Colota, G. and Jana, T., (2009). Risk analysis. The University of petrosani, economics, 9(1), 93-100.

Committee of Sponsoring Organization, (2013). Internal control integrated framework executive summary. Jersey City: COSO.

Dicksee, L.R., (1905). One of the earliest writing on internal control and the auditor, USA, New York Press

Dorrah, A. and Alsabbagh, A., (2008). Management of human resources.

London: Greenbook publication.

Frazer, L., (2011). "The effect of internal control on the operating activities of small restaurants", Journal of Business and economics research, 16(6),361-374. 
Getie, M., James, K. and Mula, J., (2010). "Antecedents and organizational performance implication of internal audit effectiveness some propositions and research Agenda". Pacific Accounting Review. 22(2), 224-252.

Hailemarian, S., (2014). Determinants of internal audit effectiveness in the public sector: case study in selected Ethiopian public sector offices, Jimma University.

Institute of internal auditors, (2012). International standards for the professional practice of Internal auditing.

Internal Control: Providing a Foundation for Accountability in Government An introduction to internal International Organization of. (n.d.). International Organization.

Jackson, R. and Stent, V. (2010). Effect of Internal control on fraud detection and prevention in District Treasuries of KaKamega country. International journal of business and management. 4(1), 47-57.

Jitpaiboon, T. (2014). The study of competitive priorities and information technology selection: exploring buyer and supplier performance. Journal of international technology and Information management, 23(1), 91-124.

Keski, S., (2016). The effects weak Internal controls and their Remediation under SOX 404 on audit fees, Erasmus University.

Kingdom, U., Abdullahi, M. H., \& Muturi, W. (2019). Effect of Internal Control Systems on Financial Performance of Distribution Companies in Kenya. Research Journal of Finance and Accounting, IV(12), 762-780. https://doi.org/10.7176/rjfa/10-20-02

Kumuthinidevi, S. (2016). "A study on effectiveness of the internal control system in the private Banks of Trincomalee", International journal of scientific and Research publication, 6(6), 600-613.

Lawal, M.L. (2005). "Unions and whistle- Blowing in University Honesty and Integrity Proceedings of the third National Conference on Ethical Issues in Accounting, BUK.

Leng, J., and Li, L., (2011). Analysis of the Relationship between listed companies, Earning quality and Internal Control Information Disclosure. Modern economy, 2(1),893-900.

MOF, (2018). Ministry of finance, Annual performance Review of public enterprises.

Musika, W. and Upping, P., (2014). Evaluation of Internal Control efficiency in Finance department of RMUTI Sakon Nakhan Campus. World journal of social sciences, 4(3),139-148. 
Ndifion, E. and Patrick, E., (2014). "The Impact of Internal Control Activities on Financial Performance of Tertiary Institutions in Nigeria”, Journal of Economics and Sustainable Development, $5,(16), 156-165$

Oseifuah, E. and Gyekye, B., (2013). "Internal control in small and micro enterprises in the Uhembe district, Limpopo", province. South Africa Eur. sci. journal, 9(4),49-63.

Puttick, G. and Van Esch, S., (2007). The principles and practice of internal controls, New York: Best publication.

Ratcliffc, T.A. and Landes, C.F., (2009). Understanding Internal control and internal control services, New York: American Institute of certified public Accountants.

Sabrens, G., Visscher, C. D. and Vangils, D., (2010). Risk management and internal control in the public sector: An in depth analysis of Belgian social security public Institutions, Jimma University.

Salmah, M. S., (2010). Contemporary concepts in financial and Internal control, Delhi: Delhi publication.

Shabri, S. M., Saad, R. and Barkar, A. A. (2017). The effects of internal control system on cooperatives's profitability: A case of koperasi ABC Berhad, International review of management and marketing, 6(8), 240-245.

Sawyer, L.B., Dittenbofer, M. A. and Scheiner J.B., (2003). Internal Auditors, USA, The institute of internal Auditors.

Shamsuddin, N. and Johari, N., (2014). "The effect of Internal Audit towards Internal Control System Effectiveness", E- proceedings of the Conference on Management and MuamalahKole $J$ Universiti Islam Antarabangsa Selanger 26(6),36.

Terrell, J., (1974). A conceptual Auditing Methodology Interrelations Between the Financial Statements Internal controls and the audit program. The Accounting Reviews, 5(3),176-180.

The role of internal control in enhancing corporate governance evidence form jorden. Internal journal of business and management, 10(7)57.

Vaittinen, A., (2015). Internal control, risk management and internal audit in Finnish public company, Jyvaskyla University.

Vollbehr, L., (2014). Implementing the monitoring activities component if the coso frame work, Aalto University.

Wardiwiyono, S., (2012). Internal control system for Islamic micro financing, An exploratory study of Baitul Maal wat Tamwill in the city of Yogyakarta Indonesia. International journal of 
Islamic and Middle Eastern finance and management, 5(4), 340-352. 